\title{
Symbolika i funkcja postaci literackich w Labiryncie świata i raju serca Jana Amosa Komeńskiego
}

\author{
Symbolism and function of literary characters in Labyrinth of the World \\ and Paradise of the Heart by John Amos Comenius
}

DOI: $10.34739 /$ szk.2021.08.09

\begin{abstract}
Streszczenie: Prezentowane badania dotyczą funkcji i symboliki postaci w Labiryncie świata i raju serca Jana Amosa Komeńskiego. W utworze tym podlegają one w znacznym stopniu typizacji i są przykładami, które służą autorowi do pogłębionej refleksji duchowej. Cechy negatywne bohaterów są często przez Komeńskiego ukazywane w kostiumie zwierzęcym. Symboliczne skojarzenia ze światem fauny odsyłają do sfery wewnętrznej człowieka i unaoczniają jego kondycję moralną.
\end{abstract}

Słowa kluczowe: Jan Amos Komeński, barok, labirynt, postać literacka

\begin{abstract}
The presented research concerns the functions and symbolism of the characters in Labyrinth of the World and Paradise of the Heart by John Amos Comenius. In this work, the characters are largely typified and are examples that serve the author's in-depth spiritual reflection. The negative features of the heroes are often shown by Comenius in animal costumes. Symbolic associations with the world of fauna refer to the inner sphere of man and show his moral condition.
\end{abstract}

Keywords: Comenius, baroque, labyrinth, character

Obiektem prezentowanych badań jest arcydzieło czeskiej prozy barokowej Labirynt świata i raj serca (Magnuszewski, 1973: 91) w jego polskojęzycznej wersji tłumaczonej na początku XX wieku przez ks. Jana Pindóra (Komeński, 1914). Przedmiotem dociekań jest natomiast deskrypcja znaczeń symbolicznych, jak też określenie funkcji bohaterów literackich w rzeczonym dziele w szerszym kontekście kulturowym i literackim.

Na wstępie należy podkreślić, iż Labirynt świata Jana Amosa Komeńskiego - wybitnego umysłu epoki baroku, teologa i pedagoga (Sitarska, 2014: 
31-61; Richter, 2018) - to zbeletryzowany traktat alegoryczny, który ma wyraziście zarysowaną fabułę. Józef Magnuszewski przekonywał, iż ten barokowy tekst wyrasta ponad literaturę czeską siedemnastego stulecia, jak też późniejsze dokonania autora (Magnuszewski, 1973: 91; Borkowski, 2015: 27). Tytułowy utwór ukazuje wędrówkę młodzieńca po osobliwym mieścieświecie. Jak w soczewce Komeński odsłania tu wielość zachowań ludzkich, pragnień i ambicji jednostek oraz grup społecznych, którym permanentnie towarzyszy groza utraty życia, zdrowia czy majętności. Miasto-świat czeskiego myśliciela jest miejscem niebezpiecznym i groźnym, dlatego też peregrynant poszukuje trwałego punktu oparcia w niestałej doczesności, którym okazuje się sam Chrystus.

Grozę położenia bohatera unaocznia ów tytułowy „labirynt”, będący niezwykle popularnym motywem-symbolem nauki oraz sztuki barokowej (Borkowski, 2017: 109-110). Wiele cennych informacji na temat labiryntu w kulturze dawnej można odnaleźć w monografiach Gustava R. Hocke (Hocke, 2003) oraz Paolo Santarcangelego (Santarcangeli, 1982). Włoski monografista przekonywał, że labirynt odgrywał istotną rolę w umysłowości epoki: „Dla ojca Atanazego Kirchera - tego straszliwego, uniwersalnego geniusza baroku - wewnętrzna część naszej planety zawiera labirynt nie do rozwikłania. Ale już przed nim wielu kosmografów usiłowało przedstawić świat, a nawet wszechświat, w formach mniej lub bardziej labiryntowych (i to typu labiryntu na ogół rzecz biorąc „uporządkowanego”), gdzie w końcu dadzą się uwięzić nawet wolne duchy wiatrów" (Santarcangeli, 1982: 287). Ponadto podkreśla się, iż człowiek wieku siedemnastego pragnie porządkować ten społecznomaterialny chaos, poszukując rozmaitych dróg wyjścia poprzez chociażby wiedzę matematyczną, gromadzenie danych o charakterze encyklopedycznym, ale też - dodajmy - przez budowanie systemów filozoficzno-religijnych, które próbowały wyjaśniać w sposób całościowy skomplikowaną, meandryczną naturę świata. Jedyne wyjście z tego doczesnego labiryntu dylematów, kwestii i problemów natury poznawczej i moralnej upatrywał Komeński w ścieżce duchowej (mistycznej) oraz dostępie do wiedzy najwyższej - pansoficznej (Komeński, 1973: 101).

W Labiryncie świata narracja prowadzona jest w pierwszej osobie. Bohater opowiada o wkroczeniu w skomplikowaną przestrzeń miasta-świata i przedkłada czytelnikowi wiedzę wysnutą niejako z autopsji, co ma niewątpliwie dodatkowy walor dydaktyczny. W tej wędrówce nie pozostaje jednak sam, bowiem towarzyszą mu osobliwe postaci, których rolą jest kierowanie uwagą głównego bohatera oraz wpływanie na postrzeganie przez niego rzeczywistości czy wprost wybór wartości i sposobu życia. Spotyka zatem Wszystkowiedza z przydomkiem Wszędybył (V̌̌ezvěd Všudubyd) oraz Oma- 
mienie (Mámeni) (Komeński, 1914: 9-10; Komenský, 1970: 17, 19). Obie postaci są sługami Królowej Mądrości, która - co ujawnia Wszędybył - nazywana bywa przez „półmędrków” Marnością. To określenie wskazuje na pewien myślowy zamysł, który zdradza autor już na wstępie dzieła, ujawniając jego podglebie starotestamentowe (Koh), a zarazem nowotestamentalne. Chodzi tu zwłaszcza o 1 List do Koryntian św. Pawła i ten oto fragment, w którym Apostoł retorycznie pyta: „Gdzie jest mędrzec? Gdzie uczony? Gdzie badacz tego, co doczesne? Czyż nie uczynił Bóg głupstwem mądrości świata?” (1 Kor 1,20); Komeński powróci do tej myśli Pawła z Tarsu w rozdziale poświęconym filozofom. Zatem obie postacie wpisują się $\mathrm{w}$ fałszywy z punktu widzenia mądrości Bożej obraz doczesności, co powoli i metodycznie odkrywa młodzieniec. Odsłanianie gorzkiej prawdy o świecie skutkuje wewnętrznym smutkiem bohatera, który w finale dzieła zostaje uleczony czy też przemieniony przez samego Chrystusa.

W poszczególnych rozdziałach utworu pokazywane i komentowane są zachowania ludzi oraz ich profesje. Kwestie wypowiadane są „na głos” oraz ukazują się również czytelnikowi w rozbudowanych monologach wewnętrznych głównego bohatera. Ten zabieg wskazuje na swoistą dwudzielność świata przedstawionego, który jawi się w określonych opozycjach: jawne skryte, ciche - głośne, mądre - głupie, dobre - złe, piękne - brzydkie, prawdziwe - fałszywe etc. Odsłania to już rozdział pierwszy $O$ przyczynach puszczenia się w świat, w którym bohater ujawnia pogłębioną świadomość wartości, potrafiąc odróżniać dobro od zła, a następnie artykułuje potrzebę szerszej refleksji nad projektowaniem drogi życiowej, a więc wyboru profesji czy też powołania.

Postacie, które najpierw podróżny napotkał podczas swej wędrówki, to wspomniany już Wszędybył oraz Omamienie. Pierwszego cechuje nie tylko szybki chód czy bystry wzrok, ale przede wszystkim spryt oraz biegłość w retoryce i filozofii. Mniej wyraziście jawi się druga z postaci: „(...) nie mogłem rozeznać czy to mąż czy kobieta, bo jakąś powłoką była okryta, jakby we mgle stała" (Komeński, 1914: 10). Opis postaci, w tym zasłonięta twarz oraz jej wizualne rozchwianie, odsyła do istoty imienia, które oddać można słowem „ułuda". Imiona bohaterów, zwłaszcza Omamienie oraz Marność, wzbudziły lęk młodzieńca, gdyż w języku posiadały one negatywne konotacje. Obawy wzmogły również ich działania, a zwłaszcza nałożenie uzdy, która była wykonana z rzemienia Ciekawości (Všetečnosti), wędzidła wytworzonego z żelaza Upartości (Urputnosti) oraz okularów zrobionych ze szkła Domniemania (Domnění) - oprawa tych ostatnich wykonana była z rogu nazwanego Zwykiem (Zvyk). Te instrumenty miały odpowiednio sterować uwagą pielgrzyma, jednak nało- 
żone niechlujnie i $\mathrm{w}$ pośpiechu umożliwiały mu podglądanie świata $\mathrm{w}$ jego prawdziwej odsłonie (Komeński, 1914: 12-13).

W pierwszej chwili oglądany z wysokiej wieży świat wydał się bohaterowi rozumnie zorganizowany. Bramy miejskie unaoczniały narodziny i powołanie, rynek oraz poszczególne ulice (było ich sześć) zaludniali przedstawiciele różnych stanów. Najpierw ukazano stan rodzinny, więc rodziców, dzieci i czeladź, następnie rzemieślników oraz ludzi odpowiadających za żywność, dalej stan uczonych i duchownych, a w końcu władzę monarszą i stan rycerski. Całości obrazu dopełniał zamek, który usytuowany został na skalistym wzgórzu po stronie zachodniej miasta oraz "Gród szczęścia” (Arx Fortunae, Hrad Štěstí), który zasiedlony był przez ludzi bogatych i znacznych, cieszących się wyjątkowym powodzeniem. W centralnej części rynku przebywała Królowa świata, którą zwano Mądrością. Ten idealny niejako obraz grodu przy uważnym oglądzie ujawniał rozliczne skazy. Uwagę bohatera zwracał zwłaszcza fakt, że ulice łączyły się ze sobą niesymetrycznie poprzez wyrwy czy załomy, co dawało wrażenie nieładu czy też labiryntowości (Komeński, 1914: 14-17).

Niezwykle ważną postacią w tym mieście-świecie okazał się „zarządca powołań", czyli Los. W utworze jest to postać pozbawiona emocji, nieempatyczna, a nawet złowroga. Jawi się w tekście jako posępny starzec, który nadzoruje proces przypadkowego $\mathrm{w}$ istocie wyboru drogi życiowej przez młodych ludzi. Na wyciągniętych z miedzianej wazy karteczkach odczytywano określony nakaz - panuj, służ, walcz etc. Główny bohater uprosił dla siebie możliwość odroczenia decyzji, co było zachowaniem odbiegającym od normy. Na kartce zostało zapisane, że jego zadaniem jest rozglądać się i badać (Komeński, 1914: 17-18).

Różnorodną galerię postaci ukazano w obszernym rozdziale Pielgrzym rynek świata ogląda. Ludzie w swej masie zostali porównani przez Komeńskiego do roju pszczół, gdzie każdy z osobna zajęty był wykonywaniem jakiejś pracy, której jednak celowość i sposób realizacji okazywały się nieklarowne. Ponadto mówiono tam różnymi językami, co potęgowało wrażenie ogólnego zamieszania i wywołało u pielgrzyma skojarzenia z biblijnym Babilonem. Rynek natomiast odznaczał się wielkim nieładem (dziury, doły, porozrzucane belki), będąc zarzewiem kłótni, a nawet wojen. Próby ingerowania w takie urządzenie świata spotykały się z wrogością i agresją; bohater, chcąc przestrzec innych przed licznymi niebezpieczeństwami, sam stawał się obiektem ataków i kpin.

Uwagę narratora przyciągnął też fakt nakładania przez ludzi masek, które zdejmowano jedynie w chwili przebywania w samotności lub obcowania z ludźmi tego samego stanu. Ta strategia miała wynikać z jakiejś ostroż- 
ności, bowiem - jak można mniemać - zachowania szczere i otwarte wobec przedstawicieli innej grupy były krytycznie oceniane przez stanowe społeczeństwo. Bohater zauważył, że każdy doskonale opanował sztukę posługiwania się maskami. Komeński maluje negatywny konterfekt moralny społeczeństwa XVII w. Rywalizacja skutkuje brakiem poszanowania pracy innych, złośliwością, wyśmiewaniem szlachetnych postaw, w tym uczciwości. Szczególnie krytycznie odniesiono się tu do pychy, narcyzmu, jak też swoistej teatralności kontaktów międzyludzkich. Przyglądając się uważniej poszczególnym jednostkom, bohater ze zdumieniem odkrył, że ich ciała pokryte są wrzodami. Ponadto: „(...) niektórzy mieli pysk świni, inni zęby psa, inni rogi wołu, inni uszy osła, inni oczy bazyliszka, (...) największa ich liczba równała się małpom" (Komeński, 1914: 19-20).

Komeński zapośredniczył to obrazowanie zapewne z ówczesnej sztuki malarskiej czy drzeworytowej. Dawne polemiki wyznaniowe bywały ozdabiane chociażby obrazami duchownych, którzy mieli głowy zwierzęce - przykładem Postylla Mikołaja Reja (Stępień, 2013: 53). Ponadto pobrzmiewają tu echa popularnej w średniowieczu i renesansie metafory małpy (Curtius, 1997: 570-572). Ciekawe porównanie człowieka do koczkodana odnaleźć można u wspomnianego wyżej polskiego autora: „Prostochmy jako małpy; kiedy je łapają, / Tedy się tam przed nimi w boty ubierają. / A potym je pod drzewem z daleka położą. / Ony potym zbieżawszy też tam nogi włożą (...). 0 , rozkoszneż to małpy tu po świecie chodzą, (...) / Bowiem kto się rozumem z cnotą nie sprawuje, / Jest kotek na łańcuszku, co wszytkim kugluje" (Rej, 1975: 94). Małpa staje się zatem synonimem wątpliwej konduity, niestałości moralnej, a w końcu śmieszności.

Ważną postacią w Labiryncie świata jest upersonifikowana śmierć. Jej wyobrażenie zaprezentowane $\mathrm{w}$ tym dziele ma korzenie średniowieczne. Johan Huizinga przypominał, że „Wizerunek śmierci od stuleci znany był w ujęciu plastycznym i literackim pod kilkoma postaciami: jako apokaliptyczny jeździec, który galopuje po stosach leżących na ziemi ciał, jako megiera zlatująca $\mathrm{w}$ dół na skrzydłach nietoperza (...), wreszcie jako szkielet z kosą lub łukiem i strzałą, czasem jadący na wozie ciągnionym przez woły, niekiedy wierzchem na wole lub krowie" (Huizinga, 1998: 175). W dziele Komeńskiego atrybutami śmierci są kosa oraz łuk i strzały. Jej rolą w utworze jest rażenie ludzi pociskami niezależnie od ich wieku i kondycji. Wielu umierało od tych strzał od razu, inni chorowali, ciała zaś umarłych wrzucano do otaczającej miasto-świat ciemnej jamy. Los tych ludzi jest dla bohatera exemplum krótkotrwałości ludzkiego istnienia, powodowanej często przez niemoralne postępki (m.in. rozwiązłość, porywczość, niehigieniczny tryb życia) (Komeński, 1914: 18-27). 
Istotną częścią Labiryntu świata jest ogląd przez młodzieńca poszczególnych profesji oraz trybu życia ich przedstawicieli. W części Pielgrzym na stan rzemieślników patrzy bohater dostrzega wiele niedogodności i niebezpieczeństw, które są udziałem ludzi wykonujących różne zawody. Wymienił tu kowali mających popękaną skórę i uszkodzony słuch, górników, pracujących w ciemnościach i odczuwających lęk przed zasypaniem, tonących żeglarzy czy przepracowanych rolników. Ponadto dostrzega ogrom problemów materialnych i społecznych ludzi pracujących, w tym brak oszczędności, kradzieże, nieuczciwą konkurencję, handel towarami niskiej jakości. Bohater zauważa, iż ludzie pomijają aspekt duchowy swego istnienia, co owocuje wewnętrznym niepokojem i błądzeniem w poszukiwaniu jakiejś życiowej pełni. Jego zdziwienie wywołuje fakt, iż nawet ci żeglarze, którzy przeżyli burzę morską, wracali do swej profesji, szukając dalej materialnego zysku, i nie troszczyli się o własną duszę (Komeński, 1914: 27-39).

W satyrycznym ujęciu prezentuje Komeński stan uczonych. Nadzieje na życie spokoje i dostatnie niweczą obrazy osobliwych procedur i egzaminów, którym byli poddawani adepci nauki. Oburzenie wzbudzały nie tylko wysokie koszty kształcenia, ale też kary cielesne zadawane mniej pojętnym lub krnąbrnym studentom. Również wędrowiec dostał się do tegoż stanu, przeszedłszy „(...) te wszystkie przeobrażenia, choć nie bez trudności i bez utrapienia" (Komeński, 1914: 42). Ludzie uczeni w Labiryncie świata Komeńskiego jawią się jako postacie okaleczone, które utraciły określone zmysły - ślepe czy też pozbawione języka. Niekiedy są to medyczni hochsztaplerzy, którzy nie dociekali przyczyny choroby, a jedynie starali się zbyć lekarstwa. $\mathrm{W}$ tym celu opatrywali swe medykamenty pięknymi napisami czy nawet wierszami.

W centrum życia uczonych ukazano bibliotekę, która wyposażona była w rozliczne słowniki, wypisy ze źródeł, komentarze. Jej użytkownicy odznaczali się osobliwymi zachowaniami, jak chociażby spożywaniem fragmentów ksiąg, co może odsyłać do wiedzy jedynie erudycyjnej, niepraktycznej lub też zjawiska plagiatowania, zresztą potępianego przez Komeńskiego. Ponadto jedni, tracąc bibliotekę np. z powodu pożaru, nie byli w stanie zbyt wielu rzeczy bez książek powiedzieć, inni, posiadając wielkie księgozbiory, nie korzystali z nich. Na podstawie obserwacji sporów natury filozoficznej bohater wyrobił sobie też negatywną opinię o myślicielach, którzy zajmowali się w swych potyczkach intelektualnych - w opinii narratora - mało istotnymi kwestiami. W tej galerii filozofów zjawili się m.in.: Sokrates, Arystoteles, Platon, Pitagoras i inni, a każdy z nich robił coś odmiennego. Pielgrzymowi trudno było w tych labiryntach teorii dobrze orientować się, szczególnie że niektóre koncepcje wzajemnie się wykluczały. Jedynie słowa Pawła z Tarsu na 
temat mądrości przypadły do gustu podróżnemu (1 Kor 3,18-20) (Komeński, 1914: 40-52).

Młodzieniec na swej drodze spotkał również retorów, kaligrafów oraz poetów. Wszystkie te profesje przy bliższym oglądzie wydały mu się mało poważne. Sztuka słowa nawet najbardziej kunsztowna i wyszukana ukazywała słabszą stronę natury człowieczej, czego świadectwem były chętnie czytywane, często nieprzystojne, bajki i fraszki. Ponadto zazdrość o sławę poetycką prowadziła piszących do kłótni. Również przyrodnicy, matematycy, geometrowie, jak też astronomowie i astrolodzy nie przekonali wędrowca do swych racji, a ich koncepcje wydały mu się mało użyteczne (Komeński, 1914: 52-60).

Szczegółowemu oglądowi poddał również bohater alchemię i medycynę. Pochwały na temat wytapiania złota i rzekomej długowieczności, jaką miałoby gwarantować odnalezienie tego szczególnego kamienia - „nasienia życia", równoważy on skutkami ubocznymi pracy alchemika, podrażnieniami oczu, a nawet śmiercią. Bohater krytycznie przygląda się również działaniom medyków, szczególnie obraz operacji pacjenta czy też sekcji zwłok wzbudza w nim odrazę. Mimo tego, że medycyna gwarantowała zyski, to jednak poprzez fakt, iż wielu pacjentów umierało, lekarze narażenie byli na krytykę i niechęć (Komeński, 1914: 63-67). Należy w tym miejscu dodać, że w obiegu literackim w okresie baroku krążyło wiele tekstów ujawniających wrogi stosunek do ówczesnych lekarzy. Przykładem drobna twórczość polskiego poety Wacława Potockiego. W wierszu Doktorowie poeta podkreślał, że w dawnej Turcji nieskuteczni lekarze bywali uśmiercani (Potocki, 1987: 408).

W dalszych partiach dzieła wędrowiec podpatruje pracę prawników. Początkowo profesja ta wydała mu się niezwykle szlachetna, ale przy bliższym oglądzie zauważył, iż ogromna energia ludzka marnotrawiona jest na sprawy mało istotne. Zaciekawienie wzbudza w nim również promocja doktorów i magistrów. Huczne uroczystości oraz towarzysząca nabywaniu tytułów korupcja budzą niesmak bohatera, który potęguje fakt, iż ci uczeni nie potrafią nawet czytać i pisać (Komeński, 1914: 67-71). Zainteresowania peregrynanta skupiają się również na kwestiach religijnych. Obserwuje zatem różne wyznania, nawiedzając budowle sakralne, gdzie dostrzega wśród wyznawców liczne słabości natury teologicznej oraz osobliwości praktyk religijnych. Bogaty wystrój świątyń chrześcijańskich prowadzi do duchowego rozproszenia oraz idolatrii, czyste świątynie muzułmańskie kontrastują z okrucieństwem ich wyznawców, w żydowskich zaś panuje modlitewny hałas (Komeński, 1914: 71-74).

W Labiryncie świata zawarto wiele informacji na temat organizacji rządów w mieście-świecie oraz sposobu funkcjonowania reprezentantów władzy. Przewodnik utwierdza bohatera w tym, iż ten stan zarezerwowany jest 
dla ludzi wybitnych i zdolnych. Przy bliższym oglądzie okazało się jednak, że po władzę sięgają jednostki przebiegłe oraz majętne. Wielu władców było niejako okaleczonych, brak uszu powodował, że nie słyszeli oni skarg poddanych, nieliczni zaś, którzy mieli wszystkie członki, cierpieli z nadmiaru obowiązków. Okazało się, że królowie i książęta często nie posiadali odpowiednich zdolności przywódczych, a towarzyszące im zastępy zauszników i pochlebców ujawniają, że w swych decyzjach są podatni na podszepty innych. Bohater widział też upadek jednej ze stolic, któremu towarzyszyły krwawe rozruchy (Komeński, 1914: 74-80).

Szczególną odrazą napawał wędrowca stan żołnierski, a zwłaszcza rozmowy na temat sposobów zadawania innym śmierci. Dyskusje o tym wydały się podróżnemu wprost przerażające. Widział też niezwykle krwawą bitwę, która pochłonęła wiele ofiar, co wywołało jego wielki żal, a także ogromne obrzydzenie tym zawodem. Natomiast stan rycerski jawił się podróżnemu jako zepsuty moralnie. Wzajemna zawiść, swawolne życie, polowania, uczty, nadużywanie władzy względem poddanych jawiły się podróżnemu jako w istocie naznaczone piętnem marności, która jest skądinąd myślowym słowem-kluczem w Labiryncie świata (Komeński, 1914: 80-85). Osobne miejsce zajmują w omawianym dziele przedstawiciele „mediów” nowiniarze czy też gazeciarze. Bohater ze zdumieniem obserwuje wpływ przekazywanych treści na stan umysłu czytelników czy słuchaczy, którzy pod ich wpływem popadali nawet w obłęd. Mimo że rzetelna praca nowiniarska wydawała się pielgrzymowi potrzebna, to jednak zniechęcały go do niej towarzyszące temu różne napięcia, emocje oraz poważne niekiedy konflikty (Komeński, 1914: 85-88).

Fałszywą ideę szczęścia w świecie doczesnym w pełni demaskuje Komeński we fragmentach tekstu poświęconych Fortunie. Miasto, w którym przebywała owa bogini, było nieprzystępne, a prowadziła doń jedna brama. Przejście to, opatrzone imieniem Cnoty, było wąskie i wysokie, a jednocześnie przez ciernie i załomy trudno dostępne. Ludzie zatem utworzyli sobie inne rozliczne wejścia do grodu, które opatrzone były napisami: Obłuda, Kłamstwo, Pochlebstwo, Nieprawość, Fortel czy Przemoc. Na placu za murem rzesze oczekiwały na łaskawość Pani Fortuny, która ostatecznie decydowała, czy i kogo wpuści do swego zamku. Odbywało się to za pomocą koła, na które ludzie byli wciągani przez urzędnika władczyni - Przypadek. Warto dodać, że szczególnie wieki średnie unaoczniały w ten sposób przygodność zdobywania, ale też utraty powodzenia przez poszczególnych ludzi (Sokolski, 1996: 89). W Labiryncie świata wielu z oczekujących, pomimo usilnych próśb, nie doczekało się życzliwości Fortuny, co wydawało się bohaterowi obrazem nader smutnym (Komeński, 1914: 88-90). 
Mieszkańcy zamku Fortuny nie wzbudzili sympatii podróżnego. Zbudowana z trzech pięter budowla gościła najpierw bogaczy, następnie ludzi, którzy mieli dostęp do wszelakich rozkoszy, aż po tych, którzy cieszyli się wielką sławą. Kondycja owych domowników wydała się wędrowcowi godna pożałowania. Bogacze byli skuci złotymi łańcuchami, lękali się też o utratę swych dóbr, następnie wiodący życie rozkoszne żyli w upojeniu oraz z nadmiaru jedzenia chorowali, natomiast ludzie sławni często okazywali się niegodnymi rozgłosu, który zapewniała im Fama, urzędniczka Fortuny (Komeński, 1914: 91-101). Ponadto wszyscy ci mieszkańcy zamku tak samo jako inni ludzie narażeni byli na śmierć: „Na bogaczów strzały swe wysyłała, albo (...) łańcuchem złotym ich otoczywszy dusiła; rozkosznikom w ciastka nasypała jadu; mocarzów i ludzi sławnego imienia zrzucała z góry, by szyję złamali (...)" (Komeński, 1914: 102).

Ponury obraz obejrzanego świata wzbudzał sprzeciw bohatera, który dostrzegł w każdej sferze życia trudności, jak też brak możliwości osiągnięcia przez człowieka duchowej pełni. Rzeczywistość jawi się pielgrzymowi jako w istocie złudna: „My tylko mamy takie urojenia. My cień chwytamy, prawda zaś wszędzie przed nami uchodzi. Ach, nędzniż my ludzie!” (Komeński, 1914: 104). Warto podkreślić, że Komeński wkłada w usta bohatera powtarzane przez wielu poetów barokowych metafory, ukazujące marność życia ludzkiego; przykładem wiersze Mikołaja Sępa-Szarzyńskiego (Sonet I) czy Daniela Naborowskiego (Cień...).

Ostatecznie wędrowiec zostaje skonfrontowany z Mądrością, udając się do jej zamku z pozoru wykonanego $\mathrm{z}$ alabastru ( $\mathrm{w}$ istocie był to papier), pięknie zdobionego i pilnie strzeżonego. Przed wejściem do twierdzy został on przez strażników wyposażony w okulary i uprząż. W pięknej sali ujrzał Królową, której towarzyszyły kobiety: Pilność, Rozwaga, Prawda, Gorliwość, Czystość i inne. Byli też tam rycerze - Chytrość i Potęga. Potęgę Mądrości demaskuje Salomon, który przybył do Królowej, chcąc ją poślubić, a następnie, gdy okazało się to niemożliwe, rozeznać się w tym, co jest na świecie mądrością, a co wydaje się głupstwem. Ponadto do zamku Mądrości przybyło wielu mędrców, w tym Sokrates, Platon czy Arystoteles. Rządy Królowej przy bliższym oglądzie okazały się nieskuteczne, co wywołało gniew Salomona. Wykrzykując biblijną maksymę „marność nad marnościami” (Koh 1,2), ściągnął zasłonę z jej twarzy, odsłaniając jej szpetotę i cuchnący oddech. W ramach zemsty Królowa nakazała usidlić biblijnego władce, posyłając doń Chytrość i Rozkosz, co doprowadziło do upadku tegoż króla oraz wojny w królestwie (Komeński, 1914: 105-124).

Obraz upadku króla Salomona staje się momentem przełomowym dla dalszych losów bohatera, który ujawnia przemożną chęć ucieczki z tak urzą- 
dzonego świata. Pozbawiony towarzystwa Wszędybyła i Omamienia odrzuca okulary, chcąc ujrzeć świat w prawdzie. Doszedłszy na skraj świata kieruje swą żarliwą modlitwę do Boga, prosząc o miłosierdzie. Przemianę wewnętrzną bohatera prezentuje rozdział Pielgrzym do domu trafit, w którym bohater ma wizję, widząc w swym sercu promień światła rozjaśniający jego mroki. W tym świetle dostrzega obrazy, na których wypisano imiona cnót (Ostrożność, Pokora, Sprawiedliwość, Wstrzemięźliwość, Czystość). W końcu zjawia się sam Chrystus, który po ojcowsku przemówił do niego łagodnymi słowami, pouczając go, w jaki sposób ma żyć i modlić się. Przemienionemu wędrowcowi doprawiono anielskie skrzydła oraz posłano go między ludzi. Następnie bohater odnalazł pokój wewnętrzny dzięki miłości Bożej oraz nauczył się tego, iż teologia powinna wypływać z serca. Jego wiarę ugruntowują też skromni i pracowici nauczyciele, którzy nie obawiali się śmierci. Jej obraz jest skrajnie odmienny od popularnych dawniej wyobrażeń, bowiem ta przybrana była w szaty samego Jezusa Chrystusa. W końcowej wizji Komeński odsłania obraz Królestwa Bożego, miejsca utworzonego z najdroższych i najpiękniejszych kamieni: szmaragdu, szafiru czy jaspisu. Niezliczone zastępy anielskie chwaliły Stwórcę. Na koniec Jezus udziela wsparcia pielgrzymowi, nakazując mu kochać mniej rzeczy ziemskie od samego Boga (Komeński, 1914: 126-141).

Podsumowując trzeba podkreślić, że postacie w Labiryncie świata i raju serca są w znacznej mierze stypizowane i pozbawione cech indywidualnych. Są to przedstawiciele poszczególnych stanów społecznych (uczeni, żołnierze, rzemieślnicy itd.). Wynika to ze struktury gatunkowej dzieła, a zwłaszcza jego cechy alegoryczności (w tego rodzaju tekstach istotne jest docieranie do znaczeń ukrytych, odsyłających do kwestii moralnych i duchowych). Oczywiście w mniejszym zakresie typizacji podlegają postacie o ugruntowanej kulturowo pozycji, szczególnie filozofowie antyczni, ale też postacie z Pisma Świętego. Trzecim typem bohaterów są chociażby spersonifikowane pojęcia Chytrości, Potęgi, Fortuny czy Mądrości. Komeński wpisuje się tym samym w reguły dawnej tradycji kulturowej, zmierzającej do alegoryczno-symbolicznej wizualizacji idei, czego znamiennym przykładem była Ikonologia Cesare Ripy (Ripa, 2002).

Należy też dodać, że negatywne cechy bohaterów uwypuklane są przez biskupa Braci Czeskich za pomocą symbolicznych konotacji związanych ze sferą fauny, czyli nadawania poszczególnym postaciom w utworze cech chociażby świni, małpy, psa, osła, wołu, a nawet mitycznego bazyliszka. Znaczenia te odsyłają do sfery moralno-duchowej człowieka, unaoczniając jego słabość i grzeszność. 


\section{Bibliografia}

Biblia Tysiq̨clecia, wyd. 3, Poznań - Warszawa 1982.

Borkowski Andrzej, Лабиринты дискурсов в славянских литературах эпохи барокко. Религия -политика - общество, Siedlce 2015, s. 29-48.

Borkowski Andrzej, Wieża Babel i labirynt - o symbolicznych unaocznieniach podróży w dziełach Jana Amosa Komeńskiego w kontekście kultury barokowej, w: B. Sitarska (red.), Współczesne recepcje Jana Amosa Komeńskiego, „Siedleckie Zeszyty Komeniologiczne, seria pedagogika” 2017, t. IV, s. 105-114.

Curtius Ernst Robert, Literatura europejska i łacińskie średniowiecze, tłum. Andrzej Borowski, wyd. 2, Kraków 1997.

Hocke Gustav Rene, Świat jako labirynt: maniera i mania w sztuce europejskiej w latach 1520-1650 i współcześnie, tłum. Marek Szalsza, Gdańsk 2003.

Huizinga Johan, Jesień średniowiecza, tłum. Tadeusz Brzostowski, oprac. Henryk Barycz, wyd. 6, Warszawa 1998.

Komeński Jan Amos, Labirynt świata i raj serca, tłum. ks. Jan Pindór, Cieszyn 1914.

Komeński Jan Amos, Pampaedia, tłum. Krystyna Remerowa, wstęp Bogdan Suchodolski, Wrocław 1973.

Komenský Jan Amos, Labyrint světa a ráj srdce, red. Antonín Škarka, Praha 1970.

Magnuszewski Józef, Historia literatury czeskiej. Zarys, Wrocław 1973.

Potocki Wacław, Dzieła, oprac. Leszek Kukulski, t. I, Warszawa 1987.

Rej Mikołaj, Wybór pism, oprac. Jan Ślaski, Warszawa 1975.

Richter Manfred, Johann Amos Comenius und das Colloquium Charitativum von Thorn 1645. Ein Beitrag zum Ökumenismus, 2. Auflage, Münster 2018.

Ripa Cesare, Ikonologia, tłum. Ireneusz Kania, wyd. II, Kraków 2002.

Sitarska Barbara, O Janie Amosie Komeńskim i poczq̨tkach komeniologii, w: B. Sitarska (red.), O Janie Amosie Komeńskim i jego poglądach na edukację, „Siedleckie Zeszyty Komeniologiczne, seria pedagogika" 2014, t. I, s. 31-61.

Sokolski Jacek, Bogini, pojęcie, demon. Fortuna w dziełach autorów staropolskich, Wrocław 1996.

Stępień Paweł, Śmiech w czasach ostatecznych. Tematyka religijna w „Figlikach” Mikołaja Reja, Warszawa 2013.

Santarcangeli Paolo, Księga labiryntu, tłum. Ignacy Bukowski, red. Aleksander Krawczuk, Warszawa 1982. 